\title{
Demons and exorcism in ancient Mesopotamia
}

\section{Gina Konstantopoulos}

Faculty of Humanities and Social Sciences, University of Tsukuba, Tsukuba, Japan

\section{Correspondence}

Gina Konstantopoulos, Faculty of Humanities and Social Sciences, University of Tsukuba, Tsukuba, Japan.

Email: konsta.gina.gf@u.tsukuba.ac.jp

\begin{abstract}
This essay provides an introduction to the topic of demons and the means of opposing them in ancient Mesopotamia during the early third to late first millennia BCE. Demons and witchcraft were integrated aspects of the Mesopotamian world. They could threaten individuals, often causing illness or ill fortune, as well as target society as a whole, encroaching upon the protected and ordered world of the Mesopotamian city. There were a number of ways to counter such threats, such as protective amulets and incantations, but the foremost, particularly in the first millennium $\mathrm{BCE}$, was the figure of the assipu, or exorcist. A trained ritual professional, the ăšipu had a range of tools at his disposal, as well as the protection and sanction of the gods. This article provides an introduction to the issue of demons and exorcism by presenting four key aspects of this complex topic: first, an overview of characteristics and role of demons in Mesopotamia; second, a summary of the two notable demonic figures known as Lamashtu and Pazuzu; third, the demonic and chaotic figure of the witch; and fourth, an overview of the ăšipu and his methods.
\end{abstract}

\section{1 | A TYPOLOGY OF DEMONS}

The cultures and societies of ancient Mesopotamia, a region which ranged geographically from the Assyrian north to the Babylonian south and chronologically from the third to late-first millennia BCE, were populated by a range of monstrous or supernatural figures, found in an diverse array of both quantity and kind. These beings were an integrated aspect of Mesopotamia's different societies, with textual attestations found throughout its histories. Over the veritable millennia, these figures could and did take on different shapes and forms, and the measures designed to counter them evolved alongside these changes.

This article presents an overview of these beings, as well as other supernatural threats, such as the figure of the witch, that they existed alongside. Given the range of locations and wide chronological span under review, this article 
inevitably flattens a level of the complexities inherent in these figures and the ways in which details of their presentation were, to some degree, dependent on the specific context of both time and space. Little is entirely constant over such a long time period of time, except perhaps that no matter what the period, the threats these figures posed had to be addressed and countered. This could be achieved in a number of ways; from simple apotropaic amulets and figurines, often designed for household use, to long series of ritual incantations, written in Akkadian and Sumerian over multiple cuneiform tablets. The range of such curative and apotropaic approaches was designed to address any possible situation.

Given this wide array of demonic figures seen in Mesopotamia, perhaps the first problem to arise when discussing them is one of definition, swiftly followed by issues of typology and taxonomy. The English word "demon" is inherently problematic, implying a duality of good and evil that was not present in Mesopotamian religion and culture. Even the word "supernatural" has similar issues, as these figures were an accepted and integrated aspect of religion and society. In Mesopotamia, demons were often the external reason or cause for a number of ailments - such as illness, impotence, and even bad luck or misfortune - that could strike an individual. They could also, however, pose a threat to the society at large, to the gods, and to the fundamental ordered nature of the universe. Thus, there is already a great deal of ambiguity in their actions, but we must introduce still more. Demons, which we may understand as beings beyond the human sphere in their abilities, origins, and actions, could in some cases act either positively or negatively, fulfilling the former function when they were set as protection against another demonic threat (Konstantopoulos, 2017; Schwemer, 2018).

The ease by which the same specific demonic figure could act benevolently or malevolently suggests that they did not possess fixed natures, but should instead be considered and classified by their actions. For example, demons did not, generally, receive offerings, but even here we see exceptions: the demonic Sebettu rage against their lack of offerings in the first millennium incantation series Udug Hul (Geller, 2015), but there is evidence for temples dedicated to the figures from the mid-second millennium BCE onwards. Similarly, the kūbu demon, who embodied stillborn children, could cause disease and illness but also appears as a theophoric element in personal names and was worshipped in shrines from as early as the late third millennium BCE (Valk, 2016, pp. 732-734). Other figures appear to move in and out of the category of the demonic based upon the context wherein they appear. The Mesopotamian witch (kaššāptu) showcased traits that one would consider demonic: she is chaotic and has abilities beyond the human sphere. Those powers, however, were attached to a human figure, sometimes quite directly given the attestations of witchcraft accusations that were levied against individuals.

Given all of these complications, the term demon remains a compromise of sorts, employed to describe a collective that by its very nature often shifts. The emic Sumerian word often translated as "demon" is udug, a word that is paired with the Akkadian word utukku. This term could have two applications, used either to refer to a specific demonic figure - that is, "the udug" - but also applied as a title for a broader group of demonic beings, which may include a variety of other individually named figures. Thanks in part to this dual application, the udug was among the most shapeless and formless of all demonic figures in Mesopotamia (Geller, 2011). Other demons were far more specific, associated with concepts such as a particular illnesses or certain time of day (Wiggermann, 2007a).

Scholarly attempts at categorizing or organizing the demonic denizens of Mesopotamia have taken different approaches: some overviews organize demons and monsters along lines of order and chaos (Sonik, 2013); others consider the literature and language, be it Sumerian or Akkadian, used to represent them (Verderame, 2013). Other scholarship (Hutter, 2007; Wiggermann, 2011) has divided them by form and function, creating a number of categories such as monsters, which tend to be associated with specific geographic locations; "evil demons"; demonic diseases; ghosts (ețemmu) and wandering spirits, some of which were also associated with necromancy (Finkel, 1983; Scurlock, 2016); wild animals and chaotic beings; the numina loci of deserted and wild spaces; demonic conceptualizations of time periods or hours of the day; and demonic representations of abstract concepts, such as fear, battle, or strife. Some of these categories were more easily conceptualized than others, and monsters and beasts in particular were given clear physical features. The dragon-snake beast known as the mušhuššu, for example, was famously 
depicted on the glazed bricks of the Ishtar gate of Babylon as a four-legged chimerical creature, while other monstrous figures have identifiable, if smaller-scale, artistic depictions (Wiggermann, 1992, pp. 185-187).

While most demons attacked individuals, some posed larger, more existential threats to society - and some did both. The Sebettu, for example, were a collective of seven demons who could trouble society and civilization as a whole, but could also appear to menace an individual, if less frequently (Konstantopoulos, 2015; Verderame, 2017). The larger destructive powers of the Sebettu could also be directed either positively or negatively. In the first millennium BCE literary text Erra and Išum, the Sebettu rage against the land itself, longing for the glory of battle (George, 2013, pp. 47-65). However, this fury may equally be directed against the enemies of the land and the text eventually utilizes the Sebettu as a weapon on behalf of Mesopotamia. This malleability was a common trait to demons, who were characterized less by any inherent and inflexible nature and more by their actions. Demons were far from the only supernatural threat to Mesopotamian society and its inhabitants; constant ill fortune could be the result of witchcraft or of one losing the favor of their personal deity, situations the asšipu, or exorcist, could also address through the use of incantations (Jacques, 2015; Lambert, 1974). Moreover, the gods themselves could rage against humanity, and several literary texts in both Sumerian and Akkadian tell of the gods sending down a massive flood with the intent of destroying civilization. Demons fit well into such a dangerous world, where the gods could be both capricious and cruel.

\section{2 | DEMONIC OUTLIERS: LAMASHTU AND PAZUZU}

In contrast to more amorphous figures such as the udug, several demons in Mesopotamia came parceled with their own unique and striking characteristics, identity, and even iconography. The most famous of these was Lamashtu, a female demon found in iconographic representations from the early second millennium BCE onwards (Wiggermann, 2000). Lamashtu was countered by an extensively detailed series of ritual incantations (Farber, 2014) that had the ancillary benefit of describing her and the full range of her qualities. Although her iconography and characteristics develop and change over time, and also seem to acquire different characteristics according to their region of origin, Lamashtu has certain qualities that remain present, to some degree, throughout her attestations (Wiggermann, 2000, pp. 220-224). Known by seven names, the first among these was often the "Daughter of Anu," placing her within a specific - and originally divine - genealogy. The incantation series continues to describe how "in view of her unseemly deeds, (Anu) forced her to step down and denied her a place of worship on earth" (Farber, 2014, p. 155). Lamashtu was thus once divine, presumably even a goddess. She had been stripped of that rank and the offerings that were owed it because of her habit of preying on the young, particularly infants and pregnant women - her aforementioned "unseemly deeds." Her punishment only accelerated and intensified her crimes, and Lamashtu was the primary demonic threat to target the young.

There was a certain and undeniable logic to Lamashtu's position and prominence. Pregnancy in Mesopotamia was a dangerous affair, and death to either mother or child during pregnancy, in childbirth, or in the early stages of infancy was common. To be sure, other demons could also threaten new or still expectant mothers: as already mentioned, the kübu demon was linked to both miscarriage and stillbirth (Römer, 1973). Lamashtu was the most prominent of such threats by far, however, and her iconography was furthermore representative of the dangers she embodied (Scurlock, 1991), as can be seen in two fairly typical apotropaic plaques from the first millennium BCE (Figures 1 and 2). The once-goddess is shown as a hybrid creature with a lioness's head; her mix of animal and human features a common trait of demonic and monstrous creatures as a whole. Her many-taloned hands clutch at snakes, and she nurses a piglet and puppy at her pendulous breasts. Incantations designed to counter the demoness often cite her desire to nurse infants at her own breasts, though her milk bears poison and illness. In essence, Lamashtu represented the inversion of the concept of motherhood, a clear perversion of the natural order.

Lamashtu was not the only demonic creature defined by feminine aspects: the spectral ardat-lilî, who drifted in from the steppe on the breeze to haunt men at night was essentially the ghost of a young woman who died 

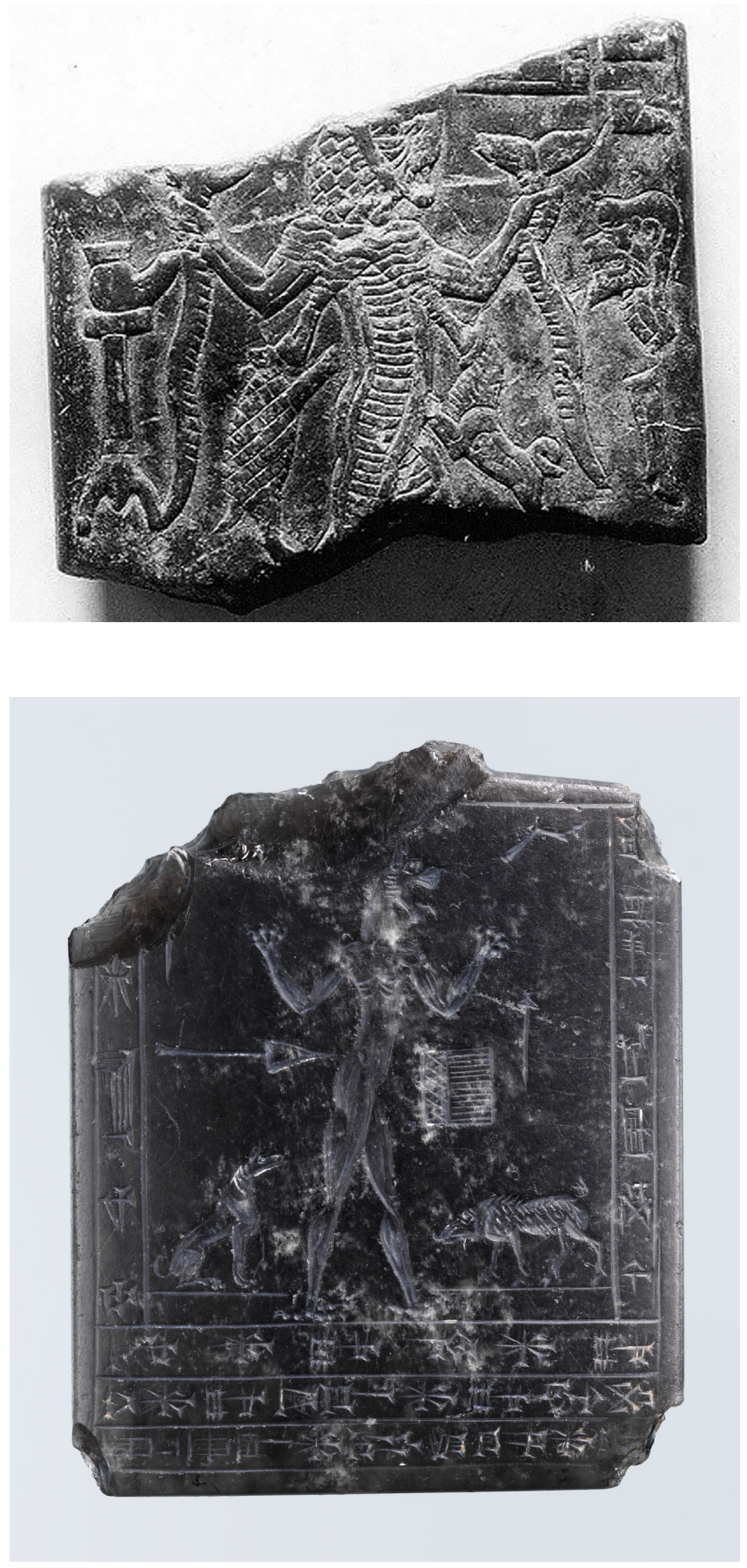

FIGURE 1 Plaque against the Demon Lamashtu (Assyria, c. 7th - 6th c. BCE; Limestone, $5 \times 6.2 \times 1.4 \mathrm{~cm}$; MMA 86.11.2 $@$ Metropolitan Museum of Art)

FIGURE 2 Amulet against the Demon Lamashtu (Assyria, c. early first millennium BCE; Obsidian, $5.7 \times 4.7 \times 0.9$ cm; MMA 1984.348 @Metropolitan Museum of Art)

unmarried. This state of affairs, which was aberrant to the natural order of Mesopotamian society, transformed the spirit of the woman into the ardat-lili, who was then driven to haunt men (Farber, 1989; Geller, 2000, pp. 331-332; Lackenbacher, 1971). Given her distinct iconography, Lamashtu was far more attached to her feminine qualities, but her origin is not without its complications. One of Mesopotamia's flood stories, the Akkadian myth Atra-hasis from the early second millennium BCE (Lambert \& Millard, 1969), describes how the gods themselves established 
Lamashtu as a built-in control measure against unchecked population growth. This embedded her in the natural order of the universe and ran counter to her more prevalent, once-divine, now-demonic, origin story. As the incantations to counter Lamashtu from this early period align with her more common traits rather than what is seen in Atra-hasis, its alternate portrayal of her origins and role may stem from its place as a literary text, rather than an incantation.

Lamashtu's vivid iconography and rich textual imagery led to the proliferation of her textual and artistic representations, from number of different locations and periods. Though many of the major incantations to oppose her were composed (or compiled) in the first millennium BCE, we see examples from the early second millennium. Furthermore, representations of Lamashtu travel to locations outside of Mesopotamia, and are found in sites such as Ugarit, in Syria, and Byblos, on the Lebanese coast (Nougayrol, 1969, 1971). Many examples of Lamashtu's major incantation series were recovered from the archival settings of the library of the Neo-Assyrian king Ashurbanipal (Tonietti, 1979, p. 302), but the spread of amulets, which ranged from the expensively elaborate to the simple and even mould-produced, speak to the threat she posed to everyday life. An early textual example, an incantation found in a domestic context from the Old Assyrian site of Kanesh, in modern-day Turkey, shows a singular level of modification, tailored and targeted for specific and personal use (Barjamovic, 2015).

The incantations intended to counter Lamashtu were carried out by the āšipu, the Mesopotamian ritual specialist and exorcist, and primarily relied on sympathetic magic, a common feature of Mesopotamian magic (van Binsbergen \& Wiggermann, 1998). By making a figurine of Lamashtu and performing rituals upon it, the effect could be transferred to the demoness herself. In one method, the figurine was set beside the afflicted individual, and following several days of ritual, placed with a figurine of a black dog and then buried outside the city wall. As black dogs were associated with and sacred to Gula, the goddess of healing (Böck, 2013; Plantholt, 2017), they were an ideal check on the demoness. In another ritual, a similar figurine of Lamashtu was placed by the afflicted and subjected to ritual incantations; following these, the figurine was provided with provisions and buried again outside the city wall. In this method of expulsion, Lamashtu's provisions were intended to sustain her on her enforced journey away from the city, through the increasingly wild fields, marshes, and rivers, until she finally reached the mountains that guard the gates to the Netherworld.

Particularly in this last ritual method, Lamashtu was often countered by another uniquely identified and named figure: the demon Pazuzu (Heeßel, 2002, 2011). Pazuzu was employed as a protection against Lamashtu, and his distinctive masculinity also contrasted with the demoness (Figure 3). When portrayed in full, Pazuzu is shown with a snarling, bestial head, clawed hands, and taloned feet. His bears a set of four wings, prominent ribs, and an erect, snake-headed penis. His protection was particularly sought by pregnant women, and pendants of the demon - or, most often, his snarling head - were clearly intended to be worn (Figure 4). Pazuzu enjoys a degree of modern renown thanks to his role in the 1971 horror novel The Exorcist and subsequent film, although Hollywood decided to cast him as the villain despite his actual apotropaic function. The demon only appeared to oppose Lamashtu and thus conferred protection upon the women and infants she would otherwise target. Pazuzu's incantations hint at a more complicated background for the demon, as he states in one: "I am Pazuzu, son of Hanpu, king of the evil winddemons. I ascended a mighty mountain that quaked, and the (evil) winds that I ran into there were headed West. One by one, I broke their winds" (Borger, 1987; Wiggermann, 2007b, p. 126). Given Pazuzu's general activities, the "mighty mountain that quaked" in this incantation may be interpreted as a woman in active and difficult labor, or at least, represent her heavily gravid form. Pazuzu underscores once again the complex nature of demons: the figure is employed protectively, warding off Lamashtu, and yet Pazuzu himself claims kingship of the "evil wind-demons," with the Sumerian "hul" used, a word that had clear connotations of malevolence.

Pazuzu's origins, particularly his kingly status, remain obscure, though it has been suggested that he may connect to earlier rulers (Frahm, 2018b). Textual and artistic references, which have a broad geographic distribution, are only found from the early first millennium BCE onwards. Moreover, the demon's terrifying visage moves beyond Mesopotamia, appearing in sites in the eastern Mediterranean, such as the island of Samos (Graff, 2014). As with the monstrous Humbaba, who appeared in a number of Sumerian and Akkadian texts connected with the famous hero-king Gilgamesh (Edzard, 1990, 1991; George, 2003), the demon's gaze, as the locus of his power, was transformed into 


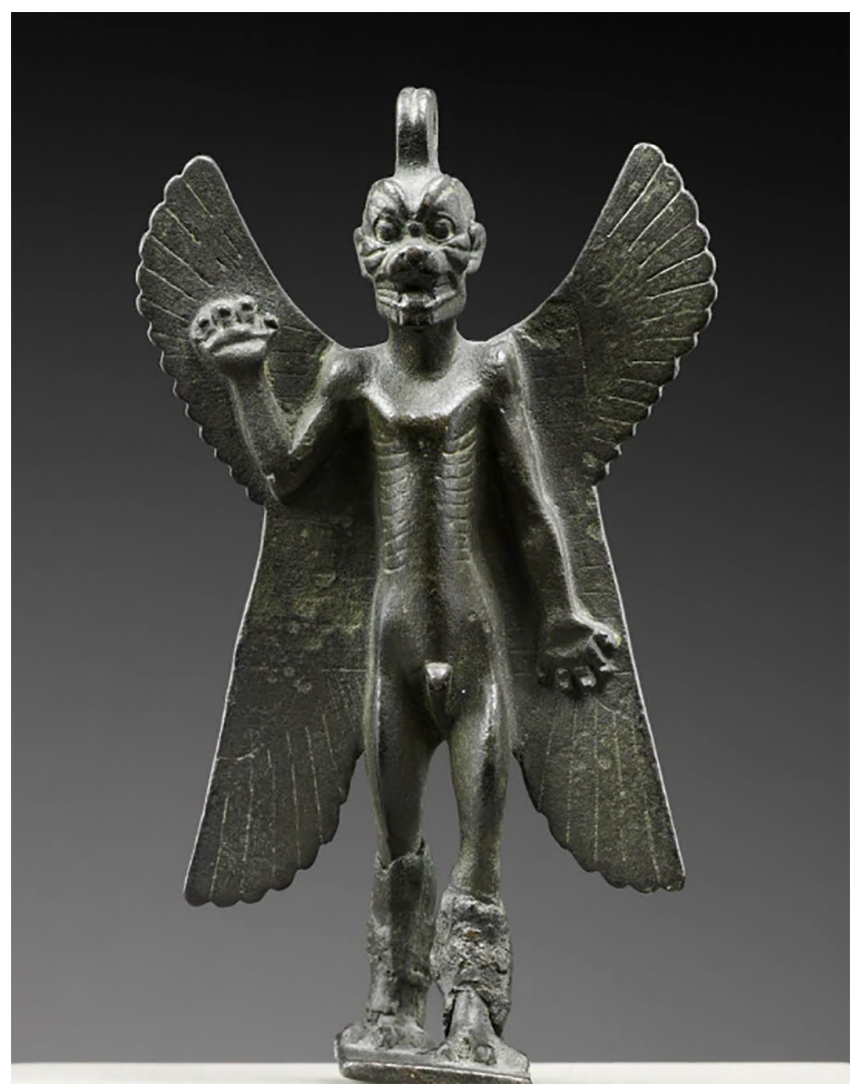

FIGURE 3 Statuette of Pazuzu

(Mesopotamia, 8th-7th c. BCE; Bronze, $15 \times 8.6 \times 5.6 \mathrm{~cm}$; MNB 467 (Musée du Louvre)

his most portable, and thus widely-traveled, aspect (Graff, 2013; Schwemer, 2018, pp. 173-174). Gaze and lines of sight hold a similar power, if on a larger scale, when considering the apotropaic reliefs of monstrous and demonic figures found in Assyrian palaces in the first millennium BCE (Neumann, 2015). In Pazuzu's case, though he was himself demonic and inherently terrifying, his gaze was a powerful weapon that could be leveled against Lamashtu, offering protection against the threat she posed.

\section{3 | THE WITCH}

Lamashtu's status as the most prominent of antagonistic female demonic figures - a specific category, to be sure was only challenged in Mesopotamia by the witch (munus-ušz-zu, or kaššāptu). Unlike the named and individually personified witches that populated Greek and Roman sources, figures such as Circe, Medea, and Erichtho, to name but a few (Spaeth, 2014) the Mesopotamian witch operated on a cosmic scale, as a nameless and often demonic entity (Abusch, 1989). A complicated figure, and deserving of her own dedicated survey, I will only highlight here some of her more essential points and the recent scholarship to consider her. Perhaps best rendered as "malevolent magic-user," we also see evidence for the male "witch," or kaššāpu, though he usually appears in conjunction with the more frequently attested female figure. There is a large body of incantations dedicated to countering the effects of Mesopotamian witchcraft, which could manifest in a number of forms. These anti-witchcraft texts have been now been collected in three published volumes (Abusch \& Schwemer, 2010, 2016; Abusch, Schwemer, Luukko, \& Van Buylaere, 2020). The witch was also countered by the incantation series known as Maqlû, or "the Burning," a complicated text that was the purview of the Mesopotamian exorcist. The series is best known from the first millennium 
FIGURE 4 Pendant with the Head of Pazuzu (Assyria, c. 8th - 7th c. BCE; Bronze, $4.3 \times 2.65 \times 2.65 \mathrm{~cm}$; MMA 1993.181 @Metropolitan Museum of Art)

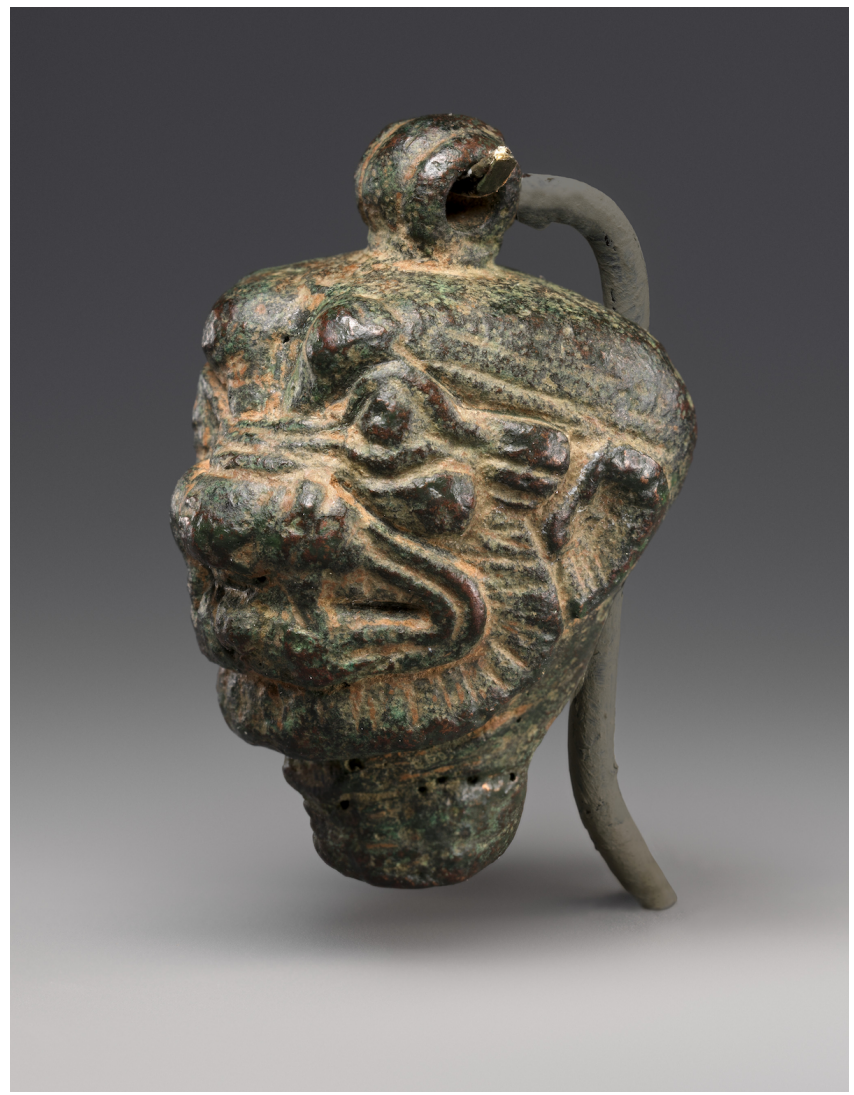

BCE, in a standard recension comprised of 10 cuneiform tablets. Maqlû has its roots in an earlier, and shorter, second millennium version that, despite its brevity, still used fire to counter the witch (Abusch, 1990). In it, the witch, who is most often female, causes chaos and harm, with her actions described in some detail: "(the witch is) she who roams the streets, who continually intrudes houses, who prowls in alleys...she robbed the fine young man of his virility, she carried off the attractiveness of the fine young woman...she has driven away my god and goddess from my person" (Abusch, 2015, p. 305). The witch was too powerful to be merely exiled to the Netherworld; instead, she was burned so that her spirit would rise, like smoke, to the heavens, where the great gods could deal with her.

Despite the prevalence of anti-witchcraft incantations, there is relatively little evidence for the presence of actual witches in Mesopotamia or the persecution of them. We only have records of one court case that levels an outright accusation of witchcraft, as recounted in five letters from the Old Babylonian period (Walters, 1970). Even here, the accusation of witchcraft seems ancillary to the major complaint. The plaintiff, one lli-iddinam accuses his son of refusing to give him the proper share of a harvest, and alleges that the matter was influenced by his son's wife and mother-in-law, both of which he names as witches. The outcome of the dispute is not known, unfortunately, though other tablets among the five related letters cite witnesses who spring to the women's defense. Beyond this, witchcraft accusations are discussed in the Code of Hammurapi ( $\mathrm{CH} \S 2$ ) and the Middle Assyrian law codes (A §47), which date to the early and late second millennium BCE, respectively. In each, however, the accused may be a man or a woman (Roth, 1997). Both references describe the punishment for false witchcraft accusations and the way the accused could prove their own innocence - principally by undergoing the judgment of the River Ordeal. Unlike later examples of witchcraft river ordeals (Tóth, 2008), survival confirmed one's innocence and brought down punishment on the accuser. Witches and witchcraft accusations may also be found in letters from Mari, also from the Old Babylonian period (Durand, 1988, p. 514). Scattered references continue in the first millennium, with one interesting letter 
from the seventh century BCE discussing how the writer has sent many sorceresses to the king, presumably for his judgment (Parpola, 1993, No. 371; see also overview in Schwemer (2007b, pp. 118-127). The overall death of appearances of the witch as an actual human figure underscore again the complexities in her own nature. There were clearly times where individuals in Mesopotamia desired to tie the threat of witchcraft (kišpu) or its perceived ill effects directly to an individual. Such accusations target a woman as a witch, but do not relay in any detail the specifics of her purported witchcraft. The image of the witch as a chaotic and demonic figure, something larger than life and certainly greater than human, was her more prolific presentation.

In general, Mesopotamian magic was apotropaic and curative, preventing a malevolent supernatural attack or alleviating such a problem if it were already present. In contrast to the extensive body of antagonistic or aggressive magic seen in both Greece and Rome, with their respective hoards of curse tablets (katadesmos or defixiones) that could be levied by an individual against a specific person who had wronged them, offensive or antagonistic magic is rarely reported in Mesopotamia (Gager, 1999; Ogden, 1999). Curses were a fixture of many Mesopotamian treaties, to be sure, promising dire consequences to those who violated the terms of their sworn oath, but individually targeted antagonistic magic - personal malevolence, so to speak - was much rarer (Kitz, 2007). Certain types of incantations and magic, even those that were the domain of the āšipu, could be construed as aggressive to be sure (Mertens-Wagschal, 2018). Some incantations, known as Egalkurra or "Entering-the-Palace," were designed to affect the outcome of a legal case and thus distort justice (Klan, 2007). Others called for the protection of the king and destruction of the enemy, particularly while on campaign (Schwemer 2007a, 2012). Love incantations (râmu) were perhaps the most vicious of these, as they essentially and completely subjugated the will of another person (Stratton, 2014, pp. 154-164; Wassermann, 2016). Aggressive magic was recorded, and textual examples of such incantations survive, though they do appear to have been somewhat uneasy additions to the ăšipu's craft. In comparison, no written examples of kišpu, or witchcraft, have been found, and it is reconstructed entirely through the incantations that counter it (Schwemer, 2019, pp. 49-50). Magic thus stood in opposition to kišpu, which was unilaterally antagonistic and malevolent. Unlike aggressive magic as performed by the ăšipu, its goal was harm for harm's sake, without even the aim of benefiting another party.

\section{4 | THE ĀŠIPU: MESOPOTAMIA'S EXORCIST}

Given the range of supernatural threats that appeared to stalk every aspect of Mesopotamian life, it is unsurprising that a similarly powerful set of apotropaic countermeasures and curatives were required. The front-line fighter against these malevolent threats was the ăšipu, who can be loosely equated with the term "exorcist." The āšipu was

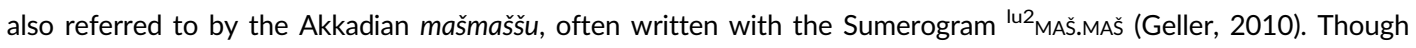
there appears to be more of a distinction between the two roles in third and second millennia, by the first millennium the boundary between the two positions has dissolved. The Sumerian term maš-maš is also seen in a number of literary texts, particularly dating to the early second millennium BCE, and seems to similarly denote a ritual specialist, or at least someone capable of performing magical practices.

The exorcist was a highly trained ritual specialist, one of a range of similarly specialized professions, which included the bārû (diviner), kalû (lamentation priest) and asû, often translated as physician or herbalist (Avalos, 1995). While the boundary between the asû and ăšipu was not always perfectly clear, in general the former treated the physiological symptoms of illness through often pharmacological means, while the latter addressed the supernatural root cause of the affliction, using ritual incantations (Jean, 2006; Ritter, 1965; Scurlock, 1999). Though such incantations are recorded from the third millennium BCE onwards (Cunningham, 1997; Krebernik, 1984; Michalowski, 1993; Zomer, 2018), information concerning the āšipu's training, as well as the larger incantation and ritual series he would have used as part of his magical toolkit, primarily date to the first millennium $B C E$, with the richest examples coming from Neo-Assyrian contexts. In particular, reconstructions of the ašipu and his training may rely on the excavated library of a private dwelling in the Assyrian city of Assur. The owners of the library may also be 
identified through the textual record, providing information on three generations of a family of exorcists, who passed the discipline down from father to son (May, 2018, pp. 62-69). The training and knowledge required of the ăšipu was extensive, as is evidenced by texts such as the so-called "Exorcist's Manual," a remarkable text from Assur that also dates to the first millennium. The manual presents a long list of texts that comprised part of the exorcist's craft (Frahm, 2018a; Geller, 2018).

The āšipu thus had a range of supernatural tools at his disposal, to aid him in his fight against the malevolent demonic forces that could bring trouble to the denizens of Mesopotamia. Foremost among these was the divine sanction inherent in his position, and the protection it conferred. The ăšipu worked with the protection and legitimation of the god Enki, or Ea, who was associated in turn with wisdom and benevolent, or overwhelmingly apotropaic, ritual magic. Though well integrated into the bureaucratic workings of the Babylonian and Assyrian palace and state, particularly in the first millennium (Radner, 2009; Steinert, 2018), the āšipu was ultimately legitimated by the gods, not the king. This legitimation took several forms: first, the ašipu was directly associated with divine figures, particularly the deities Asalluhi and Enki. In one common incantation type, known as the Marduk-Ea type and so named for the Akkadian variants of the aforementioned two deities (Falkenstein, 1931, pp. 44-76) Asalluhi, acting as a divine stand-in for the mortal āšipu, presents the affliction to his father, Enki, who proclaims that all the knowledge Enki possesses is already Asalluhi's: "My son, what do you not know? What more could I add for you? That which I know, you know as well." (Falkenstein, 1931, p. 54; Mander, 2010). Enki then commands Asalluhi to go forth and heal the patient by means of the ritual instructions he subsequently dictates. By this means, the ritual - which was performed by the āšipu himself - is given a clear mythological grounding and divine origin.

The ăšipu reinforced this divine sanction and origin by often stating in incantations that the incantation was not his, but belonged to the gods: "The spell is not my own, it is a spell of Ea and Asalluhi," as this example from the incantation series against Lamashtu states (Farber, 2014, pp. 152-153). Finally, the craft of the exorcist himself, known collectively as āšipūtu, could be attributed to the gods, specifically Enki/Ea, as seen in one scholarly text from the library of the Neo-Assyrian ruler Ashurbanipal, which decisively states of it, and several other disciplines, that: "these are of the mouth of Ea!" (Lambert, 1962, pp. 64-65). The āšipu further established his own legitimacy by connecting himself, and his profession, to the antediluvian sage, allowing him to claim a deeper, almost primeval, knowledge, a tactic also used by the ummânu, or scholar (Lenzi, 2008, pp. 103-134). Collectively, these mechanisms worked to craft the image of the exorcist as one who worked with the explicit sanction of the gods, a paladin against the wide range of demonic and otherwise supernatural threats that could attack Mesopotamian society.

This legitimation reinforced the position of the āšipu, and helped protect him in his work, while incantations served as his tools and weapons for that work. Written in Sumerian or Akkadian, as well as occasionally other cuneiform languages, incantations often included a mythological or descriptive prelude, explaining the situation and the evils afflicting the patient, and proceeded with ritual instructions to be completed in order to alleviate the situation. Though the level of performativity that was incorporated into incantations, particularly in their use by the asšipu, is still under debate, it is clear that some degree of oral recitation and performance was present in the completion of the ritual (Schwemer, 2011, pp. 423-426). By the first millennium BCE, incantations were often collected together in internally consistent incantation series that collectively worked to target particular demonic or supernatural threats. One such series, known as Šurpu, was designed in particular to counter the effects of curses and their malevolence. Though dating to the late second millennium BCE, copies were also found in the Library of Ashurbanipal (Reiner, 1958). A large and extensive series of exorcistic incantations was known simply as "Evil Demons" (udug hul in Sumerian; utukkū lemnūtu in Akkadian). Some sections are connected to earlier monolingual Sumerian forerunners (Geller, 1985); the first millennium BCE and most detailed version contains sixteen tablets, most of which are in bilingual Sumerian-Akkadian format (Geller, 2015). While many of these tablets contained incantations focused on driving out any of a number of demons, forcing them away from humans and into the distant steppe, mountains, or even Netherworld, others took a more literary tone. Tablet XI, for example, opened with a long and detailed first-person address by the god Marduk to a range of demonic entities, each of which he would eventually exorcise - and thus, which the āšipu was also given divine sanction to counter and similarly expel (Lambert, 1999). Similarly to the Šurpu 


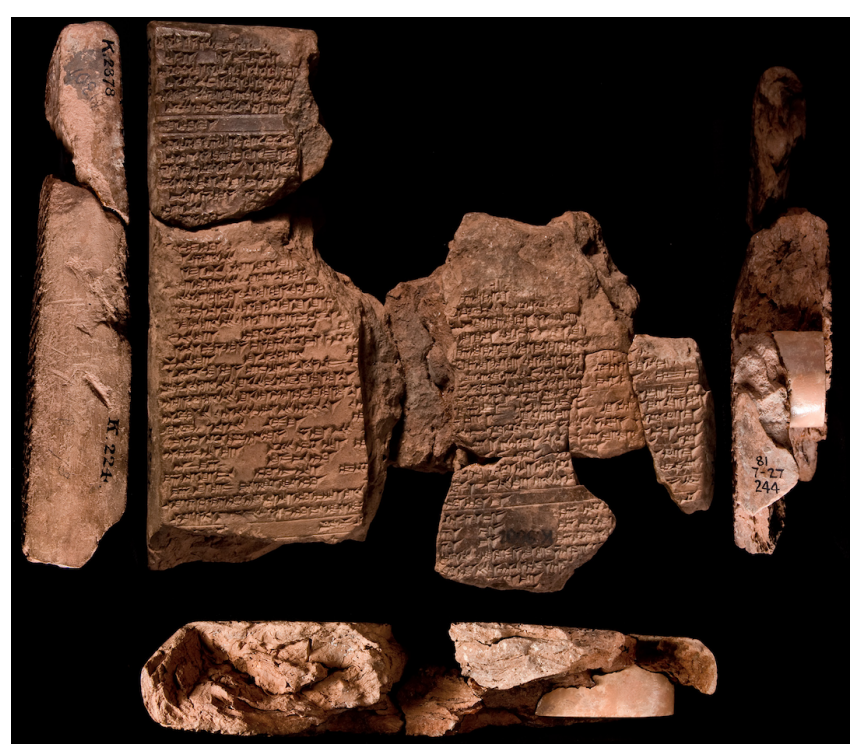

FIGURE 5 Library of Ashurbanipal; Udug Hul Tablet III (Obverse Only; Assyria (Nineveh); 7th c. BCE; K.224 and Joins; @Trustees of the British Museum)

series, this incantation series was also collected in the Library of Ashurbanipal, often on large, multi-column tablets (Figure 5).

Beyond incantations, the ăšipu also had his own helpers: benevolent monstrous or demonic figures that aided him in his work. Just as the demonic Pazuzu served to guard against Lamashtu, monstrous and demonic creatures could be tasked to protect against their malevolent counterparts. Apotropaic figurines of such creatures were found in household contexts, buried in strategic locations of a house: beneath windows, doorways, and in corners (KlengelBrandt, 1968; Nakamura, 2004). These locations were inherently liminal and thus could serve as potential points of entry and attack for supernatural malevolence. Such figurines could be accompanied by their own complex rituals, as employed in one ritual entitled "To Block the Entry of the Enemy into Someone's House" (šêp lemutti ina bit ameli parāsu), which utilizes several dozen different apotropaic figurines, including those of the cosmically dangerous Sebettu, among a full host of other monstrous creatures (Wiggermann, 1992). As previously discussed, demons in Mesopotamia were malleable in their nature and defined by their actions. So it was not unusual to see the assipu call upon his udug and lama to aid him, with both specifically identified as "good" or "benevolent" (Konstantopoulos, 2017). While the figure of the lama may have had a long history of primarily benevolent and even divine appearances (Sjöberg, 1974), the udug was truly flexible, and incantations could and did feature the benevolent udug (udug $\mathrm{sa}_{6}$-ga) fending off the malevolent udug (who could also appear as the udug hul), without any apparent distress over these diametrically opposed categories being applied to the udug within the space of one text.

In some respects, the udug and its different, but co-existent, behaviors are not only indicative of the place of demons in Mesopotamia, but also of the nature of magic and ritual itself, the system within which the āšipu found himself. Although the āšipu - unlike the udug - was only ever seen to act positively, the magic he employed was an integrated part of complex and multivalent system, one which also included and integrated its negative expressions; namely, monsters, demons, and witchcraft. The ăšipu, operating with clear divine sanction and authority, was marked as a beneficial aspect of that system, but both he and the demons he fought against can be viewed as equally natural expressions of it.

\section{ORCID}

Gina Konstantopoulos (D) https://orcid.org/0000-0002-5335-6962 


\section{REFERENCES}

Abusch, T. (1989). The demonic image of the witch in standard Babylonian literature: The reworking of popular conceptions by learned exorcists. In J. Neuzner, E. S. Frerichs, \& P. V. Flesher (Eds.), Religion, science, and magic: In concert and in conflict (pp. 27-58). New York, NY: Oxford University Press.

Abusch, T. (1990). An early form of the witchcraft ritual Maqlû and the origin of a Babylonian magical ceremony. In T. Abusch, J. Huehnergard, \& P. Steinkeller (Eds.), Lingering over words: Studies in ancient near eastern literature in Honor of William L. Moran Harvard semitic studies (Vol. 37, pp. 1-57). Leiden, the Netherlands: Brill.

Abusch, T. (2015). The Magical ceremony Maqlû Ancient magic and divination (Vol. 10). Leiden, the Netherlands: Brill.

Abusch, T., \& Schwemer, D. (2010). Corpus of Mesopotamian Anti-Witchcraft Rituals I Ancient magic and divination (Vol. 8/1). Leiden, the Netherlands: Brill.

Abusch, T., \& Schwemer, D. (2016). Corpus of Mesopotamian Anti-Witchcraft Rituals II Ancient magic and divination (Vol. 8/2). Leiden, the Netherlands: Brill.

Abusch, T., Schwemer, D., Luukko, M., \& Van Buylaere, G. (2020). Corpus of Mesopotamian Anti-Witchcraft Rituals III Ancient magic and divination (Vol. 8/3). Leiden, the Netherlands: Brill.

Avalos, H. (1995). Illness and health care in the ancient near east: The role of the temple in Greece, Mesopotamia, and Israel Harvard semitic museum monographs (Vol. 54). Atlanta, GA: Scholars Press.

Barjamovic, G. (2015). Contextualizing tradition: Magic, literacy, and domestic life in old Assyrian Kanesh. In P. Delnero \& J. Lauinger (Eds.), Texts and contexts: The circulation and transmission of cuneiform texts in social space (pp. 48-86). Berlin, Germany: Walter de Gruyter.

Böck, B. (2013). The Healing Goddess Gula: Towards an understanding of ancient Babylonian medicine Culture and history of the ancient near east (Vol. 67). Leiden, the Netherlands: Brill.

Borger, R. (1987). Pazuzu. In F. Rochberg-Halton (Ed.), Language, literature, and history: Philological and historical studies presented to Erica Reiner (pp. 15-32). New Haven, CT: American Oriental Society.

Cunningham, G. (1997). Deliver me from evil: Mesopotamian Incantations 2500-1500 BC Studia Pohl series major (Vol. 17). Rome, Italy: Pontificio Istituto Biblico.

Durand, J. (1988). Archives épistolaries de Mari I/1 Archives Royales de Mari (Vol. 26). Paris, France: Editions Recherche sur les civilizations.

Edzard, D. O. (1990). Gilgameš und Huwawa A. I. Teil. Zeitschrift für Assyriologie, 80, 165-203.

Edzard, D. O. (1991). Gilgameš und Huwawa A. II. Teil. Zeitschrift für Assyriologie, 81, 165-233.

Falkenstein, A. (1931). Die Haupttypen der sumerischen Beschwörung: literarisch Untersucht Leipziger semitische Studien (Vol. 1). Leipzig, Germany: J.C. Hinrichs.

Farber, W. (1989). (W)ardat-lilî(m). Zeitschrift für Assyriologie, 79(1), 14-35.

Farber, W. (2014). Lamashtu: An edition of the canonical series of Lamashtu Incantations and rituals and related texts from the second and first Millennia B.C Mesopotamian civilization (Vol. 17). Winona Lake, IN: Eisenbrauns.

Finkel, I. (1983). Necromancy in ancient Mesopotamia. Archiv für Orientforschung, 29, 1-17.

Frahm, E. (2018a). The "Exorcist's Manual": Structure, Language, "Sitz im Leben.". In G. Van Buylaere, M. Luukko, D. Schwemer, \& A. Mertens-Wagschal (Eds.), Sources of evil: Studies in Mesopotamian Exorcistic Lore Ancient magic and divination (Vol. 15, pp. 9-47). Leiden, the Netherlands: Brill.

Frahm, E. (2018b). A tale of two lands and two thousand years: The origins of Pazuzu. In S. V. Panayotov \& L. Vacín (Eds.), Mesopotamian medicine and magic: Studies in honor of Markham J. Geller Ancient magic and divination (Vol. 14, pp. 272-291). Leiden, the Netherlands: Brill.

Gager, J. G. (1999). Curse tablets and binding spells from the ancient world. Oxford, England: Oxford University Press.

Geller, M. J. (1985). Forerunners to Udug-hul: Sumerian Exorcistic Incantations Freiburger Altorientalische Studien (Vol. 12). Stuttgart, Germany: Franz Steiner Verlag.

Geller, M. J. (2000). Fragments of magic, medicine, and mythology from Nimrud. Bulletin for the School of Oriental and African Studies, 63(3), 331-339.

Geller, M. J. (2010). Ancient Babylonian medicine: Theory and practice. London, England: Wiley-Blackwell.

Geller, M. J. (2011). The Faceless Udug-demon. In D. O. Edzard \& M. P. Streck (Eds.), Demoni Mesopotamici (pp. 333-341). Rome, Italy: Sapienza University.

Geller, M. J. (2015). Healing Magic and Evil Demons: Canonical Udug-Hul Incantations Die babylonisch-assyrische Medizin in Texten und Untersuchungen (Vol. 8). Berlin, Germany: Walter de Gruyter.

Geller, M. J. (2018). The exorcist's manual (KAR 44). In U. Steinert (Ed.), Assyrian and Babylonian scholarly text catalogues: Medicine, magic, and divination Die babylonisch-assyrische Medizin in Texten und Untersuchungen (Vol. 9, pp. 292-312). Berlin, Germany: Walter de Gruyter.

George, A. R. (2003). The Babylonian Gilgamesh epic: Introduction, critical edition, and cuneiform texts. Oxford, England: Oxford University Press. 
George, A. R. (2013). The poem of Erra and Ishum: A Babylonian Poet's view of war. In H. Kennedy (Ed.), Warfare and poetry in the Middle East (pp. 39-71). London, England: I.B. Tauris.

Graff, S. (2013). The head of Humbaba. Archiv für Religionsgeschichte, 4, 129-144.

Graff, S. (2014). Demons, monsters, and magic. In J. Aruz, S. Graff, \& Y. Rakic (Eds.), Assyria to Iberia at the dawn of the classical age (pp. 263-271). New Haven, CT: Yale University Press.

Heeßel, N. P. (2002). Pazuzu: Archaeologische und Philologische Studien zu Einem Alt- Orientalischen Demon. Leiden, the Netherlands: Brill.

Heeßel, N. P. (2011). Evil against evil: The demon Pazuzu. In D. O. Edzard \& M. P. Streck (Eds.), Demoni Mesopotamici (pp. 357-368). Rome, Italy: Sapienza University.

Hutter, M. (2007). Demons and benevolent spirits in the ancient near east: A phenomenological overview. In F. V. Reiterer, T. Nicklas, \& K. Schöpflin (Eds.), Yearbook 2007: Angels. The concept of celestial beings - Origins, development, reception (pp. 21-34). Berlin, Germany: Walter de Gruyter.

Jacques, M. (2015). Mon dieu qu'ai-je fait? Les diĝir-šà-dab 5 -ba et la piété privée en Mésopotamie. Fribourg, Switzerland: Vandenhoeck \& Ruprecht.

Jean, C. (2006). La magie néo-assyrienne en context. Recherches sur le métier d'exorciste et le concept d'āšipūtu State archives of Assyria studies (Vol. 17). Helsinki, Finland: University of Helsinki.

Kitz, A. M. (2007). Curses and cursing in the ancient near east. Religion Compass, 1, 615-627.

Klan, M. (2007). Als das Wünschen noch geholfen hat oder: wie man in Mesopotamien Karriere machte. Eine Untersuchung zur 'dunklen Seite' der akkadischen Beschwörungsliterature des 1. Jh. v. Chr. Hamburg, Germany: Diplomica.

Klengel-Brandt, E. (1968). Apotropäische Tonfiguren aus Assur. Forschungen und Berichte, 10, 19-37.

Konstantopoulos, G. (2015). They are seven: Demons and monsters in the Mesopotamian textual and artistic tradition. (PhD dissertation). University of Michigan.

Konstantopoulos, G. (2017). Shifting alignments: The dichotomy of benevolent and malevolent demons in Mesopotamia. In S. Bhayro \& C. Rider (Eds.), Demons and Illness from antiquity to the early-Modern period. Magical and religiosus literature of late antiquity (Vol. 5, pp. 17-38). Leiden, the Netherlands: Brill.

Krebernik, M. (1984). Die Beschwörungen aus Fara und Ebla. Untersuchungen zur ältesten keilschriftlichen Beschwörungsliteratur. Hildesheim, Germany: Olms Verlag.

Lackenbacher, S. (1971). Note sur l'Ardat-Lilî. Revue d'Assyriologie et d'Archéologie Orientale, 65, 119-154.

Lambert, W. G. (1962). A catalogue of texts and authors. Journal of Cuneiform Studies, 16(3), 59-77.

Lambert, W. G. (1974). Dingir.šà.dib.ba Incantations. Journal of Near Eastern Studies, 22, 267-322.

Lambert, W. G. (1999). Marduk's address to the Demons. In T. Abusch \& K. van der Toorn (Eds.), Mesopotamian magic: Textual, historical, and interpretative perspectives Ancient magic and divination (Vol. 1, pp. 291-296). Groningen, the Netherlands: Styx.

Lambert, W. G., \& Millard, A. R. (1969). Atra-hasis: The Babylonian story of the flood. Oxford, England: Oxford University Press.

Lenzi, A. (2008). Secrecy and the gods: Secret knowledge in ancient Mesopotamia and Biblical Israel State archives of Assyria studies (Vol. 19). Winona Lake, IN: Eisenbrauns.

Mander, P. (2010). The Mesopotamian exorcist and his ego. M.G. Biga \& M. Liverani Ana turri gimilli: studi dedicati al Padre Werner R. Mayer, S.J. Quaderni di Vicino Oriente (Vol. 5, pp. 177-196). Rome: La Sapienza.

May, N. N. (2018). Exorcists and physicians at Assur: More on their education and interfamily and court connections. Zeitschrift für Assyriologie, 108(1), 63-80.

Mertens-Wagschal, A. (2018). The lion, the witch, and the wolf: Aggressive magic and witchcraft in the old Babylonian period. In G. Van Buylaere, M. Luukko, D. Schwemer, \& A. Mertens-Wagschal (Eds.), Sources of evil: Studies in Mesopotamian Exorcistic Lore Ancient magic and divination (Vol. 15, pp. 158-169). Leiden, the Netherlands: Brill.

Michalowski, P. (1993). The early Mesopotamian incantation tradition. In P. Fronzaroli (Ed.), Literature and language at Ebla Quaderni di Semitistica (Vol. 16, pp. 305-326). Florence, Italy: Dipartimento di linguistica.

Nakamura, C. (2004). Dedicating magic: Neo-Assyrian apotropaic figurines and the protection of Assur. World Archaeology, $36,11-25$.

Neumann, K. A. (2015). In the eyes of the other: The mythological wall reliefs in the southwest palace at Nineveh. Archaeological Review from Cambridge, 30(1), 85-93.

Nougayrol, J. (1969). La Lamaštu à Ugarit. Ugarit 6, 393-408.

Nougayrol, J. (1971). La Lamaštu à Byblos. Revue d'Assyriologie 65, 173-174.

Ogden, D. (1999). Binding spells: Curse tablets and voodoo dolls in the Greek and Roman worlds. In B. Ankarloo \& S. Clark (Eds.), Witchcraft and magic in ancient Europe: Greece and Rome (pp. 1-90). London, England: Athlone Press.

Parpola, S. (1993). Letters from Assyrian and Babylonian Scholars State archives of Assyria (Vol. 10). Winona Lake, IN: Eisenbrauns. 
Plantholt, I. S. (2017). Black dogs in Mesopotamia and beyond. In D. Kertai \& O. Nieuwenhuyse (Eds.), From the four corners of the earth: Studies in iconography and cultures of the ancient near east in honor of F.A.M. Wiggermann Alter orient und Altes testament (Vol. 441, pp. 165-180). Münster, Germany: Ugarit-Verlag.

Radner, K. (2009). The Assyrian king and his scholars: The Syro-Anatolian and the Egyptian schools. In M. Luukko, S. Svärd, \& R. Mattila (Eds.), Of god(s), trees, kings, and scholars: Neo-Assyrian and related studies in honour of Simo Parpola Studia Orientalia (Vol. 106, pp. 221-238). Helsinki, Finland: Finnish Oriental Society.

Reiner, E. (1958). Šurpu: A Collection of Sumerian and Akkadian Incantations Archiv für Orientforschung Beiheft (Vol. 11, p. 1958). Graz: Im Selbstverlage des Herausgebers.

Ritter, E. K. (1965). Magical expert (=ăšipu) and physician (=asû): Notes on two complementary professions in Babylonian medicine. In H. G. Güterbock \& T. Jacobsen (Eds.), Studies in Honor of Benno Landsberger on his Seventy-fifth Birthday, April 21, 1963 Assyriological studies (Vol. 16, pp. 299-311). Chicago, IL: University of Chicago Press.

Römer, W. H. P. (1973). Einige Bemerkungen zum dämonischen Gotte ${ }^{d}$ Kubu(m). In M. A. Beek, A. A. Kampman, C. Nijland, \& J. Ryckmans (Eds.), Symbolae Biblicae et Mesopotamicae: Francisco Mario Theodoro De Liagre Böhl Dedicatae Studia Francisi Scholten Memoriae Dicata (Vol. 4, pp. 310-319). Leiden, the Netherlands: Brill.

Roth, M. T. (1997). Law collections from Mesopotamia and Asia minor. Atlanta, GA: Society of Biblical Literature.

Schwemer, D. (2007a). Witchcraft and War: the Ritual Fragment Ki 1904-10-9, 18 (BM 98989). Iraq, 69, 29-42.

Schwemer, D. (2007b). Abwehrzauber und Behexung: Studien zum Schadenzauberglaben im alten Mesopotamien. Weisbaden, Germany: Harrassowitz.

Schwemer, D. (2011). Magic rituals: Conceptualization and performance. In K. Radner \& E. Robson (Eds.), The Oxford handbook of cuneiform culture (pp. 418-422). Oxford, England: Oxford University Press.

Schwemer, D. (2012). Protecting the King from Enemies, at Home and on Campaign: Babylonian Rituals on Th 1905-4-9, 67 = BM 98561. Zeitschrift für Assyriologie, 102, 209-218.

Schwemer, D. (2018). Evil helpers: Instrumentalizing agents of evil in anti-witchcraft rituals. In G. Van Buylaere, M. Luukko, D. Schwemer, \& A. Mertens-Wagschal (Eds.), Sources of evil: Studies in Mesopotamian Exorcistic Lore Ancient magic and divination (Vol. 15, pp. 173-192). Leiden, the Netherlands: Brill.

Schwemer, D. (2019). Cultural constructions of ambiguous, unsanctioned, or illegitimate ritual: Mesopotamia. In D. Frankfurter (Ed.), Guide to the study of ancient magic Religions in the Graeco-Roman world (Vol. 189, pp. 36-64). Leiden, the Netherlands: Brill.

Scurlock, J. (1991). Baby-snatching demons, restless souls, and the dangers of childbirth: Medico-magical means of dealing with some of the perils of motherhood in ancient Mesopotamia. Inc, 2, 137-185.

Scurlock, J. (1999). Physician, exorcist, conjurer, magician. In T. Abusch \& K. van der Toorn (Eds.), Mesopotamian magic: Textual, historical, and interpretative perspectives Ancient magic and divination (Vol. 1, pp. 69-79). Groningen, the Netherlands: Styx.

Scurlock, J. (2016). Mortal and immortal souls, ghosts, and the (restless) dead in ancient Mesopotamia. Religion Compass, 10 (4), 77-82.

Sjöberg, Å. W. (1974). A Hymn to dLama-sa 6 -ga. Journal of Cuneiform Studies, 26, 158-177.

Sonik, K. (2013). Mesopotamian conceptions of the supernatural: A taxonomy of Zwischenwesen. Archiv für Religionsgeschichte, 4, 103-116.

Spaeth, B. S. (2014). From goddess to hag: The Greek and Roman witch in classical literature. In K. B. Stratton \& D. S. Kalleres (Eds.), Daughters of hecate: Women and magic in the ancient world (pp. 41-58). Oxford, England: Oxford University Press.

Steinert, U. (2018). Catalogues, texts, and specialists: Some thoughts on the Aššur medical catalogue and Mesopotamian healing professions. In G. Van Buylaere, M. Luukko, D. Schwemer, \& A. Mertens-Wagschal (Eds.), Sources of evil: Studies in Mesopotamian Exorcistic Lore Ancient magic and divination (Vol. 15, pp. 48-132). Leiden, the Netherlands: Brill.

Stratton, K. B. (2014). Magic, abjection, and gender in Roman literature. In K. B. Stratton \& D. S. Kalleres (Eds.), Daughters of hecate: Women and magic in the ancient world (pp. 152-172). Oxford, England: Oxford University Press.

Tonietti, M. V. (1979). Un incantesimo sumerico contro la Lamaštu. Orientalia N.S., 48(3), 301-323.

Tóth, P. G. (2008). River ordeal - Trial by water - Swimming of witches: Procedures of ordeal in witch trials. In G. Klaniczay \& É. Pócs (Eds.), Witchcraft mythologies and persecutions (pp. 129-163). Budapest, Hungary: Central European University Press.

Valk, J. (2016). "they enjoy syrup and ghee at tables of silver and gold": Infant loss in ancient Mesopotamia. Journal of the Economic and Social History of the Orient, 59, 695-749.

van Binsbergen, W., \& Wiggermann, F. (1998). Magic in history: A theoretical perspective and its application to ancient Mesopotamia. In T. Abusch \& K. van der Toorn (Eds.), Mesopotamian magic: Textual, historical, and interpretative perspectives Ancient magic and divination (Vol. 1, pp. 1-34). Leiden, the Netherlands: Brill. 
Verderame, L. (2013). "their divinity is different, their nature is distinct!" nature, origin, and features of demons in Akkadian literature. Archiv für Religionsgeschichte, 4, 117-128.

Verderame, L. (2017). On the early history of the seven Demons (Sebettu). In D. Kertai \& O. Nieuwenhuyse (Eds.), From the four corners of the earth: Studies in iconography and cultures of the ancient near east in Honor of F.A.M. Wiggermann Alter orient und Altes testament (Vol. 441, pp. 283-296). Münster, Germany: Ugarit-Verlag.

Walters, S. D. (1970). The sorceress and her apprentice: A case study of an accusation. Journal of Cuneiform Studies, 23(2), 27-38.

Wassermann, N. (2016). Akkadian love literature of the third and second millennium BCE Leipziger Altorientalistiche Studien (Vol. 4). Leipzig, Germany: Harrassowitz.

Wiggermann, F. A. M. (1992). Mesopotamian protective spirits: The ritual texts Cuneiform monographs (Vol. 1). Groningen, the Netherlands: Styx.

Wiggermann, F. A. M. (2000). Lamashtu, daughter of Anu. A profile. In M. Stol (Ed.), Birth in Babylonia and the bible: Its Mediterranean setting (pp. 217-252). Groningen, the Netherlands: STYX Publications.

Wiggermann, F. A. M. (2007a). Some demons of time and their functions in mesopotamian iconography. In H. Spieckermann \& B. Groneberg (Eds.), Die Welt der Götterbilder Beihefte zur Zeitschrift für die alttestamentliche Wissenschaft (Vol. 376, pp. 102-116). Berlin, Germany: Walter de Gruyter.

Wiggermann, F. A. M. (2007b). The four winds and the origins of Pazuzu. In C. Wilcke (Ed.), Das geistige Erfassen der Welt im Altern Orient: Beiträge zu Sprache, Religion, Kultur und Gesellschaft (pp. 125-166). Leipzig, Germany: Harrassowitz.

Wiggermann, F. A. M. (2011). The Mesopotamian pandemonium: A provisional census. In D. O. Edzard \& M. P. Streck (Eds.), Demoni Mesopotamici (pp. 302-319). Rome, Italy: Sapienza University.

Zomer, E. (2018). Corpus of Middle Babylonian and Middle Assyrian Incantations Leipziger Altorientalische Studien (Vol. 9). Leipzig, Germany: Harrassowitz.

\section{AUTHOR BIOGRAPHY}

Gina Konstantopoulos is an assistant professor in the History of Ancient Western Asia at the University of Tsukuba. She previously held postdoctoral positions at the University of Helsinki and Institute for the Study of the Ancient World. She studied Assyriology at the University of Michigan, receiving her doctorate in 2015; after which she was a visiting assistant professor at the Institute for the Study of the Ancient World. Her research has focused on Sumerian and Akkadian literary texts, as well as the study of religion and magic in the ancient Near East, especially the place of demons and monsters in Mesopotamia, and several of her publications focus on this theme. Her doctoral dissertation, currently under contract with Brill, explored the role of one group of supernatural figures, known as the Sebettu, examining their appearances in texts, their utilization in the political sphere, and the development of their official cult. Her current research examines conceptions of space and place in Mesopotamia, with particular focus on the intersection of distant space and empire in the first millennium BCE, and she has edited a special issue of Journal of Ancient Near Eastern History (2017) as the proceedings of a workshop on this topic.

How to cite this article: Konstantopoulos G. Demons and exorcism in ancient Mesopotamia. Religion Compass. 2020;14:e12370. https://doi.org/10.1111/rec3.12370 